\title{
Using the spirometry to indicate respiratory exercises for elderly with Parkinson's disease
}

\author{
O uso da espirometria na indicação de exercícios \\ respiratórios para idosos com Doença de Parkinson
}

\author{
Daniela Guimarães, Gabriel Duarte, Karen Trippo, Graziella Furtado, Jamary Oliveira Filho, \\ Daniel Dominguez Ferraz*
}

\begin{abstract}
Introduction: Respiratory dysfunction is the main cause of death in Parkinson's disease (PD) patients and bronchoaspiration pneumonia is the most common clinical respiratory complication. Objective: To assess respiratory function of elderly with PD in mild to moderate phase of the disease. Methods: A crosssectional study was carried. Elderly in 2 to 3 PD Hoehn \& Yahr stage have participated. A single researcher has evaluated maximal inspiratory pressure (MIP), maximal expiratory pressure (MEP), thoracoabdominal amplitude, forced vital capacity (FVC) and expiratory volume in the first second (FEV1). Results: Sixty elderly have participated and their all spirometry and manovacuometry parameters presented significant differences $(\mathrm{p}<0.05)$ comparing with predicted values, except for FVC ( $\mathrm{p}=0.25)$. Only umbilical level did not reach normal values on cirtometry parameters. Patients classified as a restrictive disorder presented significant decrease in thoracic expandability. However the participants classified as an obstructive disorder showed significant decrease in expiratory muscle strength and peak expiratory flows. Conclusion: Elderly in mild or moderate phase of PD presented reduction in respiratory parameters. Spirometry showed to be
\end{abstract}

\footnotetext{
DG: BS, e-mail: danielaguimaraes25@hotmail.com

GD: BS, e-mail: gabriel.duarte@ufba.br

KT: Doctoral student, e-mail: karentrippo@superig.com.br

GF: BS, e-mail: graziellasantosfurtado@hotmail.com

JOF: PhD, e-mail: jamary@mail.harvard.edu

DDF: Doctoral student, e-mail: danieldf@ufba.br
} 
an important tool to evaluate respiratory function and to indicate the modality of respiratory exercise. Our results suggest the indication of thoracic flexibility exercises for patient with PD classified as restrictive disorder and strength exercise of respiratory muscles for those classified as obstructive disorder.

Keywords: Aged. Parkinson Disease. Respiratory Function Tests. Exercise.

\section{Resumo}

Introdução: Disfunções respiratórias são as principais causas de morte em pacientes com Doença de Parkinson (DP) e a pneumonia por bronco-aspiração é a complicação respiratória mais comum. Objetivo: Avaliar a função respiratória de idosos com doença de Parkinson (DP) em fase leve a moderada da doença. Métodos: Foi realizado um estudo transversal. Participaram idosos nos estágios 2 a 3 da classificação de Hoehn \& Yahr. Um único pesquisador avaliou a pressão inspiratória máxima (PIM), pressão expiratória máxima (PEM), amplitude toracoabdominal, capacidade vital forçada (CVF) e volume expiratório forçado no primeiro segundo (VEF1). Resultados: Sessenta idosos participaram e todos os seus parâmetros de espirometria e manovacuometria apresentaram diferenças significativas $(p<0,05)$ em comparação com os valores previstos, exceto a CVF $(p=0,25)$. Somente o nível umbilical não atingiu valores normais nos parâmetros da cirtometria. Pacientes classificados como distúrbios restritivos apresentaram diminuição significativa na capacidade de expansão torácica. No entanto, os participantes classificados como transtornos obstrutivos mostraram diminuição significativa na força muscular expiratória e dos fluxos expiratórios máximos. Conclusão: Os idosos em fase leve ou moderada da DP apresentaram redução nos parâmetros respiratórios. A espirometria mostrou ser uma ferramenta importante para avaliar a função respiratória e para indicar a modalidade do exercício respiratório. Nossos resultados sugerem a indicação de exercícios de flexibilidade torácica para pacientes com DP classificados como distúrbios restritivos e exercícios de força da musculatura respiratória para aqueles classificados como desordem obstrutiva.

Palavras-Chave: Idoso. Doença de Parkinson. Testes de Função Respiratória. Exercício.

\section{Introduction}

Parkinson's disease (PD) is a degenerative and chronic disease of the central nervous system, which results in death of substantia nigra dopaminergic neurons and causes a decrease in dopamine of nigrostriatal pathway $[1,2]$. It mainly affects the population above 65 years old and it is estimated a prevalence of 100 to 200 cases per 100,000 inhabitants [3], approximately 1 to $2 \%$ of the world population [4].

PD is among the major diseases affecting the elderly [5] affecting 1 in 100 people over 75 years and 1 in every 1000 people over 65 years [6]. Due to the increase in life expectancy around the world, it is estimated that more than 40 million people will have PD around $2020[6,7]$.

The main clinical signs of PD are bradykinesia, resting tremor, rigidity, postural changes and balance deficit $[1,2,8]$. However, repercussions of PD affect musculoskeletal system and others, including respiratory system [8].

Trunk flexion posture, corporal changes caused by aging, reduction of motion chest and decreased extension trunk movement may promote respiratory dysfunctions in this population [5]. Weakness of respiratory muscle strength, especially expiratory muscles which decrease proportionally during disease evolution, also participates in respiratory dysfunctions process [8]. So, elderly with PD presents low pulmonary volumes, decreased thoracic expandability and cough effectiveness deficit [5].

However, respiratory impairment is usually unnoticed in early stages of the disease. The patients usually reports respiratory discomfort in more advanced stages, when the disturbances are already more aggravated [9]. In early disease stages, sedentary lifestyle of elderly with PD also reduces the level of activity and physical effort, promoting 
initial respiratory adaptations or problems in respiratory function [8 - 10].

Respiratory dysfunction is the main cause of death in PD patients and bronchoaspiration pneumonia is the most common clinical respiratory complication [5, 9]. Although respiratory changes are the main cause of mortality in individuals with PD, there are still few studies that aim to evaluate respiratory function and thus guide the composition of physiotherapeutic prevention and treatment programs $[10,11]$.

However, it is not common to evaluate respiratory function and to treat respiratory dysfunctions of patients with PD. So, the objective of this study was to evaluate the respiratory function of elderly in the mild to moderate phase of PD.

\section{Methods}

We performed an observational, quantitative and cross-sectional research. The study was carried out in accordance with the Declaration of Helsinki and approved by an Ethics Human Research Committee (ref no. 1.016.971). The study was conducted at the Centro de Referência Estadual de Atenção à Saúde do Idoso (CREASI) (State Reference Health Care Centre for Elderly), a public reference outpatient clinic for the elderly in Salvador, Bahia, Brazil. Data were collected in the period between June/2015 and August/2016.

Elderly ( $\geq 60$ years-old) with idiopathic PD according to the London Brain Bank Criteria [12] participated in the study. All participants complied with the inclusion and exclusion criteria. The inclusion criteria were: age 60 years or older, regular use of PD medication, 2, 2,5 or 3 points according to the Hoehn \& Yahr classification, independence for basic activities (Barthel $\geq 90$ points) and instrumental activities (Pfeffer $\leq 5$ points) of daily life, no cognitive deficit (Mini Mental State Examination $\geq 24$ points) and gait capacity without assistance. The exclusion criteria were: neurodegenerative diseases excluding PD, dementias, limiting osteomyelitis, chronic diseases (hypertension, diabetes mellitus, chronic pain), unstable cardiovascular diseases (acute and chronic heart failure, recent myocardial infarction, unstable angina and uncontrolled arrhythmias), use of alcohol and other toxic substances.
Epidemiological and clinical variables were collected to characterize the sample. It was used the Unified Parkinson's Disease Rating Scale (UPDRS) [13] and the modified Hoehn \& Yahr classification [14] to assess severity and disease progression and general health condition. The elderly were submitted to respiratory function evaluation through spirometry and manovacuometry, according to the Guidelines for Pulmonary Function Testing $[15,16]$, and cirtometry, both performed by a single physiotherapist trained.

The functional parameters evaluated were forced vital capacity (FVC), forced expiratory volume in the first second (FEV1), forced expiratory volume ratio in the first second and forced vital capacity also called Tiffeneau index (FEV1/FVC) and expiratory flow peak (EFP).

The manovacuometry was performed through an analogue manovacuometer. The functional parameters were maximal inspiratory pressure (MIP) and maximum expiratory pressure (MEP).

The cirtometry was performed using a common tape measure staggered in centimeters at the level of the axillary regions, just below the axillary fold; xiphoid, having as reference point the lower border of the xiphoid appendix; and umbilical, with the tape on the umbilical scar $[17,18]$. The evaluator monitored respiratory movements with the tape, and it was considered the greatest difference measure between the inspiration and expiration of each level, called the amplitude coefficient (AC).

The frequency distribution format of the quantitative variables was evaluated using histograms and the Kolmogorov-Smirnov test. The quantitative variables were summarized in mean and standard deviation, and the categorical variables in absolute and relative frequencies. In statistical inference, Pearson correlation coefficient was used to calculate the linear correlations, ANOVA test with Bonferroni post-test was used to compare three independent variables and paired T-test was used to compare two dependent variables. We used the Statistical Package for the Social Sciences (SPSS - version 22).

\section{Results}

Sixty elderly have participated in the study. Table 1 shows epidemiological and clinical characteristics of the sample. 
Table 1 - Epidemiological and clinical characteristics of elderly with PD attended at CREASI in Salvador/BA, 2016

\begin{tabular}{lc}
\hline Variable & Mean \pm SD \\
Age & $69 \pm 5$ \\
BMI & $25.8 \pm 3.9$ \\
HY & $2.5 \pm 0.4$ \\
UPDRS & $29.3 \pm 14.9$ \\
\hline
\end{tabular}

Note: $\mathrm{BMI}=$ Body Mass Index; $\mathrm{HY}=$ Hoehn and Yahr; UPDRS = Unified Parkinson's disease rating scale; $\mathrm{SD}=$ Standard Deviation.

Table 2 shows cirtometry results according to the AC reference value, at axillary, xiphoid and umbilical levels. The reference value adopted for normality was 4 to $7 \mathrm{~cm}[5,19]$. The participants presented reduced values only in umbilical level.

Table 2 - Cirtometry values of elderly with PD attended at CREASI in Salvador/BA, 2016

\begin{tabular}{lc}
\hline Variable & Mean \pm SD \\
& AC \\
\hline Axillary & $6.03 \pm 2.06$ \\
Xifoidian & $5.10 \pm 2.48$ \\
Umbilical & $1.70 \pm 3.52$ \\
\hline
\end{tabular}

Note: $\mathrm{SD}=$ Standard Deviation; $\mathrm{AC}=$ Amplitude Coefficient.

A significant difference $(\mathrm{p}=0.022)$ was observed in axillary level in relation to sex. Males presented a better result $(6.52 \pm 2.26)$.

Table 3 shows the spirometry and manovacuometry values performed and predicted, in relation to sex, weight, age and height. All variables presented significant $(\mathrm{p}<0.05)$ reduced values comparing to predicted ones, except FVC.
Table 3 - Spirometry and manovacuometry values of elderly patients with PD attended at CREASI in Salvador/BA, 2016

\begin{tabular}{lcccc}
\hline \multirow{2}{*}{ Variable } & \multicolumn{4}{c}{ Mean \pm SD } \\
& Expected & Performed & $\%$ & p \\
\hline \multirow{2}{*}{ FVC } & $3.42 \pm$ & $3.61 \pm$ & $105.71 \pm$ & 0.248 \\
& 0.76 & 1.51 & 37.12 & \\
FEV1 & $2.65 \pm$ & $2.15 \pm$ & $82.10 \pm$ & $<0.001$ \\
& 0.57 & 0.71 & 23.13 & \\
FEV1/FVC & $77.79 \pm$ & $63.25 \pm$ & $81.31 \pm$ & $<0.001$ \\
& 2.00 & 18.60 & 23.78 \\
EFP & $8.55 \pm$ & $3.07 \pm$ & $37.13 \pm$ & \\
& 1.94 & 1.62 & 19.68 & $<0.001$ \\
MIP & $-90.44 \pm$ & $-62.75 \pm$ & $67.73 \pm$ & $<0.001$ \\
& 13.69 & 23.50 & 24.05 & \\
MEP & $96.10 \pm$ & $64.08 \pm$ & $67.41 \pm$ & $<0.001$ \\
& 17.96 & 23.86 & 23.91 & \\
\hline
\end{tabular}

Note: $\mathrm{SD}=$ standard deviation, FVC = Forced Vital Capacity, FEV1 = Forced Expiratory Volume in the first second, EFP = Expiratory Flow Peak, MIP $=$ Maximum Inspiratory Pressure, MEP $=$ Maximum Expiratory Pressure.

A significant difference ( $p=0.021$ ) was found between FEV1 percentage in elderly with scores 2 and 3 of Hoehn \& Yahr classification. No difference was found between these stages and patients in stage 2.5 of Hoehn \& Yahr classification.

A regular and significant $(\mathrm{p}<0.001)$ correlation between FVC and AC at the axillary level, and between FEV1 and UPDRS ( $\rho=0.303, p=0.018$ ) can be observed in figure 1. A significant weak correlation $(\rho=0.269, \mathrm{p}=0.038)$ was found between EFP and MEP.
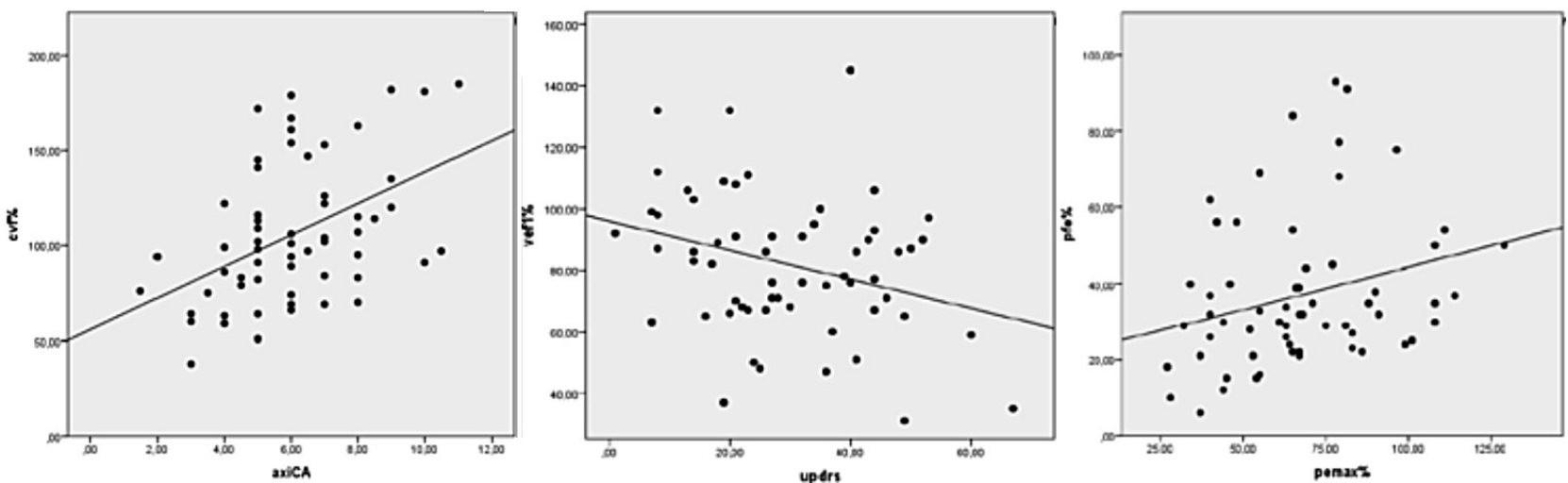

Note: $\%=$ Percentage of Forced Vital Capacity; axiAC $=$ Amplitude Coefficient at the Axillary Level; $\% 1=$ Percentage of Forced Expiratory Volume in the First Second; Revised = Unified Parkinson's Disease Rating Scale; efp\% = Expiratory Flow Peak Percentage; Pemax\% = Maximum Expiratory Pressure Percentage.

Figure 1 - Correlations between FVC\% and Axillary level AC, FEV1\% and UPDRS, EFP\% and MEP\% of elderly with PD attended at CREASI in Salvador/BA, 2016. 
Other combinations were performed among the variables studied, but no correlation was found.

In relation to respiratory disorder obtained through spirometry, $45 \%$ of the participants were considered normal (Figure 2).

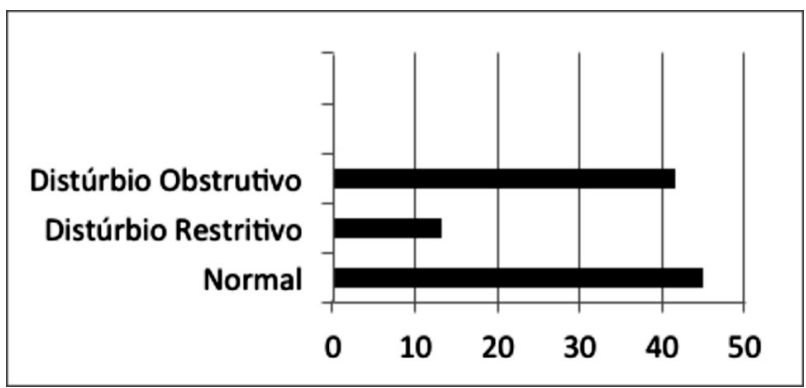

Note: Normal, $n=27$ (45\%); Restrictive Disorder, $n=8$ (13.3\%); Obstructive Disorder, $\mathrm{n}=25$ (41.7\%).

Figure 2 - Proportion of respiratory disturbance classification by spirometry in elderly with PD attended at CREASI in Salvador/BA, 2016.

A significant difference was found between axillary $(p=0.026)$ and xiphoid level $(p=0.001)$ among normal participants and elderly classified as a restrictive disorder. However, this difference was not observed between normal elderly and those classified as an obstructive disorder $(\mathrm{p}=1.00)$ at both levels.

There was also a significant difference in EFP percentage $(p<0.001)$ and MEP $(p=0.023)$ among normal elderly and those classified as an obstructive disorder. This difference was not found among normal elderly and the participants classified as a restrictive disorder (EFP: $p=0.339$; MEP: $p=0.718$ ).

\section{Discussion}

The results of this study suggest that elderly with PD in the mild to moderate stages of the disease present a reduction in respiratory parameters. Elderly with restrictive disorder present a significant decrease in thoracic expansibility, while the participants classified as an obstructive disorder present a significant reduction in expiratory muscle strength and maximal expiratory flow. Our results suggest that it is important to treat respiratory function in elderly with PD in the mild to moderate stages with exercise. Spirometry evaluation may help exercise indication. So, thoracic flexibility exercises is indicated for patient with PD classified as restrictive disorder and strength exercise of respiratory muscles is indicated for those classified as obstructive disorder.

Thoracoabdominal mobility depends, among other factors, on respiratory muscles used [20]. The participants in our study presented normal chest expansion and reduced abdominal expansibility. This abdominal expansion during inspiration is characterized by diaphragmatic breathing [20], because the diaphragm is the main muscle used for this purpose. A diaphragm dysfunction may cause this decrease in abdominal mobility. In addition, elderly with PD present alterations in respiratory drive, respiratory muscle flexibility and respiratory activation and coordination [9], which may also explain the reduction of abdominal expansion in our participants. Therefore, diaphragmatic involvement seems to occur before worsening of chest rigidity, making this reduction of abdominal mobility more evident than thoracic expansibility in early stages of PD.

Differences in the patterns of thoracoabdominal mobility between sexes in PD are not described in the literature. In our study men had significantly better chest expansion compared to women. However, studies with healthy individuals have reported that there is no difference in thoracoabdominal movement in relation to sex during resting breathing [21, 22].

Patients with PD seem to present a worse thoracic mobility comparing with controls of the same age. Ramos et al. [5] have evaluated 10 individuals with 1.5 to 5 of modified Hoehn \& Yahr scale, and they also found a decrease in thoracic mobility of their participants. Cardoso and Pereira [10] demonstrated that individuals with PD had significantly lower respiratory measures than healthy controls with similar characteristics.

Trunk extension limitation and thorax amplitude reduction decrease pulmonary compliance, making pulmonary expansion harder and promoting decrease pulmonary volumes [23]. All pulmonary measurements performed in this study were significantly lower than predicted in all variables, except for FVC. Olowabi et al. [24] also demonstrated that the values of FVC, FEV1, FEV1/FVC and PEF of elderly with PD in stages 1 to 5 on the Hoehn \& Yahr scale were significantly lower than healthy controls.

Changes in lung volumes can be observed in a short period of PD evolution. We observed a significant difference between FEV1 in elderly with 2 and 3 
stages of Hoehn \& Yahr scale. Elderly in moderate phase presented a significant lower values of FEV1 comparing with participants in the milder phase of PD. Similar results were observed in Olowabi et al.'s study [24]. These authors found that pulmonary function parameters were significantly lower in individuals with higher Hoenh \& Yahr scores. So, both results indicate that respiratory changes worsen with PD progression.

Chest expansion maybe influence the expiration volume of air mobilized, because a reduced airflow will eventually restrict pulmonary ventilation. We found a regular and significant correlation between thoracic expansibility and FVC, and also between FEV1 and disease progression. According to Cardoso and Pereira [10], a rigid chest may cause reduction of thoracic mobility and decrease of pulmonary expansion, limiting pulmonary ventilation and reducing pulmonary volumes.

In our study, obstructive disorders were more common than restrictive ones. Similar results were observed in Olowabi et al. [24] study. However, in PD restrictive lung status is more common [10] and occurs mainly due to the stiffness of thoracic wall [24]. These changes contribute to the reduction of pulmonary expansibility that can be evaluated through the spirometry.

According to Trindade et al. [25], the restrictive disorder is associated with a significant reduction of vital capacity and a maintenance or increase of FEV1/FVC. In our results, the participants performed better values of FVC comparing with the predicted, but worse values of FEV1/FVC comparing with predicted ones. These results contributed to a major reduction of FEV1 in relation to FVC, demonstrating the narrowing of airways, which characterizes obstructive ventilatory disorder.

Our participants were in the early stages of PD and do not have a significant rigidity capable of triggering restriction pictures. It seems that obstructive disorder is an early event in PD [26]. Respiratory muscle strength of our participants was significantly lower than predicted ones. The study proposed by Guedes et al. [27] corroborates with this finding. Their results confirmed that respiratory pressures in PD are lower than predicted values. This reduction in respiratory muscles strength, especially expiratory muscles, may be associated with aging process, neurological impairments, costal arches stiffening, reducing of rib cage movement and flexed posture [10, 28]. These characteristics reduce muscle capacity to generate forced flows, as well as overcome thoracic rigidity, contributing to the reduction of pulmonary volumes and respiratory pressures, especially the maximum expiratory pressure, which will worsen with the evolution of the disease [5, 27].

Strong expiratory muscles are essential to achieve an effective cough, because its contraction is the responsible for generating high velocity airflow able to remove undesirable airway materials [29]. Studies have reported that individuals with PD present a decrease in cough effectiveness due to the reduction of contraction force of abdominal musculature during reflex and voluntary cough. Decrease in sensitivity also impairs the activation of an induced cough reflex. So, respiratory system of these patients presents a real difficulty to remove airways secretions, facilitating aspiration during swallowing and consequently causing aspiration pneumonia $[29,30]$.

Our results suggest the correlation between strength of expiratory musculature and capacity to generate maximum expiratory airflows. Thus, expiratory muscle training may be an important strategy to improve respiratory muscle strength and consequently the ability to cough. Weakness of expiratory muscles induces a lower capacity to generate forced expiratory maneuvers [27], which are important for regular airway cleansing.

The main limitation of our study is the small number of participants.

\section{Conclusion}

In this study, elderly with PD in the mild to moderate phase of the disease presented a significant reduction in most of respiratory parameters. The reduction in abdominal expansion suggests that a diaphragm involvement occurs before thoracic stiffness worsens. The reduction of thoracic expansibility is the main respiratory impairment for elderly with restrictive respiratory disorder, whereas decrease of expiratory muscular force and maximum expiratory flows is the major respiratory dysfunction for elderly classified as obstructive disorder.

We recommend the use of spirometry by physiotherapists to choose the most appropriate therapeutic respiratory exercise for elderly with PD. 


\section{References}

1. Haase DCBV, Machado DC, Oliveira JGD. Atuação da fisioterapia no paciente com doença de Parkinson. Fisioter Mov. 2008;21(1):79-85.

2. Lana RC, Álvares LMRS, Nasciutti-Prudente C, Goulart FRP, Teixeira-Salmela LF, Cardoso FE. Percepção da qualidade de vida de indivíduos com doença de Parkinson através do PDQ-39. Rev Bras Fisioter. 2007;11(5):397-402.

3. Brasil. Ministério da Saúde. Protocolo clínico e diretrizes terapêuticas da Doença de Parkinson. 2010 [cited 2016 Aug 10]. Available from: https://tinyurl.com/oj7bcwx.

4. Bonjorni LA, Jamami M, Lorenzo VAP, Pessoa BV. Influência da doença de Parkinson em capacidade física, função pulmonar e índice de massa magra corporal. Fisioter Mov. 2012;25(4):727-36.

5. Ramos ML, Neves DR, Lima VP, Orsini M, Machado D, Bastos VHV, et al. Análise de parâmetros pneumofuncionais em pacientes com doença de Parkinson: estudo piloto. Rev Bras Neurol. 2014;50(2):38-43.

6. Morris ME. Movement disorders in people with Parkinson disease: A model for physical therapy. Phys Ther. 2000;80(6):578-97.

7. Goulart F, Santos CC, Teixeira-Salmela LF, Cardoso F. Análise do desempenho funcional em pacientes portadores de doença de Parkinson. Acta Fisiatr. 2004;11(1):12-6.

8. Ferreira FV, Cielo CA, Trevisan ME. Aspectos respiratórios, posturais e vocais da Doença de Parkinson: considerações teóricas. Rev CEFAC. 2011;13(3):534-40.

9. Owolabi LF, Nagoda M, Babashani M. Pulmonary function tests in patients with Parkinson's disease: A case-control study. Niger J Clin Pract. 2016;19(1):66-70.

10. Guedes LU, Rodrigues JM, Fernandes AA, Cardoso FE, Parreira VF. Respiratory changes in Parkinson's disease may be unrelated to dopaminergic dysfunction. Arq Neuropsiquiatr. 2012;70(11):847-51.

11. Parreira VF, Guedes LU, Quintão DG, Silveira EP, Tomich GM, Sampaio RF, et al. Padrão respiratório em pacientes portadores da doença de parkinson e em idosos assintomáticos. Acta Fisiatr. 2003;10(2):61-6.
12. Gibb WR, Lees AJ. The relevance of the Lewy body to the pathogenesis of idiopathic Parkinson's disease. J Neurol Neurosurg Psychiatry. 1988;51(6):745-52.

13. Movement Disorder Society Task Force on Rating Scales for Parkinson's Disease. The Unified Parkinson's Disease Rating Scale (UPDRS): status and recommendations. Mov Disord. 2003;18(7):738-50.

14. Hoehn MM, Yahr MD. Parkinsonism: onset, progression and mortality. Neurology. 1967;17(5):427-42.

15. Cardoso SRX, Pereira JS. Análise da função respiratória na doença de Parkinson. Arq Neuro-Psiquiatr. 2002;60(1):91-5.

16. Alves LA, Coelho AC, Brunetto AF. Fisioterapia respiratória na doença de Parkinson idiopática: relato de caso. Fisioter Pesqui. 2005;12(3):46-9.

17. Caldeira VS, Starling CCD, Britto RR, Martins JA, Sampaio RF, Parreira VF. Precisão e acurácia da cirtometria em adultos saudáveis. J Bras Pneumol. 2007;33(5):519-26.

18. Costa D, Forti EMP, Barbalho-Moulim MC, Rasera-Junior I. Estudo dos volumes pulmonares e da mobilidade toracoabdominal de portadoras de obesidade mórbida, submetidas à cirurgia bariátrica, tratadas com duas diferentes técnidas de fisioterapia. Rev Bras Fisioter. 2009;13(4):294-300.

19. Souza RB. Pressões respiratórias estáticas máximas. Diretrizes para testes de função pulmonar. J Pneumol. 2002;28(Suppl 3):S155-65.

20. Pereira CAC. Espirometria. Diretrizes para testes de função pulmonar. J Bras Pneumol. 2002;28(Suppl 3):S1-82.

21. Basso RP, Regueiro EMG, Jamami M, Di Lorenzo VAP, Costa D. Relação da medida da amplitude tóraco-abdominal de adolescentes asmáticos e saudáveis com seu desempenho físico. Fisioter Mov. 2011;24(1):107-14.

22. Simon KM, Carpes MF. Avaliação da mobilidade torácica em crianças saudáveis do sexo masculino pela medição do perímetro torácico. Fisioter Pesqui. 2006;13(2):6-12.

23. Caldeira VS, Starling CCD, Britto RR, Martins JA, Sampaio RF, Parreira VF. Precisão e acurácia da cirtometria em adultos saudáveis. J Bras Pneumol. 2007;33(5):519-26. 
24. Verschakelen JA, Demedts MG. Normal thoracoabdominal motions. Influence of sex, age, posture, and breath size. Am J Respir Crit Care Med. 1995;151(2 Pt 1):399-405.

25. Araujo JB, Souza MN, Silva AZ, Normando VMF, Pontes LS. Comparative study of respiratory function tests between healthy patients and carriers of idiopathic Parkinson's disease. Rev Para Med. 2010;23(4).

26. Trindade AM, Sousa TLF, Albuquerque ALP. A interpretação da espirometria na prática pneumológica: até onde podemos avançar com o uso dos seus parâmetros? Pulmão RJ. 2015;24(1):3-7.

27. Cardoso F, Dabien-Haddad L, Ribeiro A, Camargos S, Amaral S, Sulmonetti N. Função respiratória em doença de Parkinson-Pacientes não expostos a Levodopa. Arq Neuropsiquiatr. 1998;26(Suppl 1):7.
28. Fleck CS, Gerzson LR, Steidl EMS, Hernandez NM. Caracterização da capacidade funcional, nível cognitivo e força muscular respiratória de idosas com síndrome parkinsoniana. Estud interdiscipl Envelhec. 2014;19(1):109-21.

29. Pitts T, Bolser D, Rosenbek J, Troche M, Okun MS, Sapienza C. Impact of expiratory muscle strength training on voluntary cough and swallow function in Parkinson disease. Chest. 2009;135(5):1301-8.

30. Troche MS, Brandimore AE, Okun MS, Davenport PW, Hegland KW. Decreased cough sensitivity and aspiration in Parkinson disease. Chest. 2014;146(5):1294-9.

Received in $10 / 19 / 2017$

Recebido em 19/10/2017

Approved in 11/06/2017

Aprovado em 06/11/2017 